\title{
Original
}

Journal of Hard Tissue Biology 25[2] (2016) 121- 130

\section{Regenerative Capacity of Atrophic Submandibular Gland by Duct Ligation in Mice}

\author{
Keita Akadomari $^{1)}$, Akira Tanaka ${ }^{1)}$ and Izumi Mataga ${ }^{2)}$ \\ 1) Department of Oral and Maxillofacial Surgery, School of Life Dentistry at Niigata, The Nippon Dental University, Niigata, Japan \\ 2) Department of Oral and Maxillofacial Surgery, School of Life Dentistry at Tokyo, The Nippon Dental University, Tokyo, Japan \\ (Accepted for publication, December 18, 2015)
}

\begin{abstract}
Function degeneracy of the salivary gland leads to reduced protection against infection and reduced physiological function of the oral cavity, considerably diminishing the patient's quality of life. However, no method of treatment has yet been established to recover the secretory capacity of the salivary gland reduced by the degeneration or disappearance of the gland tissue. Ongoing salivary gland regeneration experiments using cell transplantation aim to introduce clinical regenerative treatment for the salivary gland. Because it is essential to understand the self-regenerative capacity that remains in the recipient's salivary gland, it is essential to search for optimal conditions for transplantation and establish a salivary gland atrophy model. In this context, we performed duct ligation of the submandibular gland in groups of mice for 7-, 14-, and 21-day ligation periods, compared immunohistochemical staining using acinar cell and stem cell markers, detected apoptosis using TUNEL staining, and analyzed gene expression using RT-PCR to search for the expression of factors related to regenerative capacity that remain in the atrophic salivary gland. All 3 periods of ligation led to remarkable atrophy/disappearance of acinar cells and the dominant presence of duct-like structures. These structures expressed stem cell markers most intensively after 14 days of ligation, and double immunostaining revealed the expressions of PSCA and c-Kit that coincided with them. AQP5 expression was detected in acinar cells and the apical membrane of the intercalated ducts in the normal submandibular gland and was also detected after 21 days of ligation in the remnant acinar cells and intercalated ducts. Conversely, the number of TUNELpositive apoptotic cells in the atrophic salivary gland was highest after 7 days of ligation. These results showed that the duct-like structures that exist after ligation expressed stem cell markers and AQP5, indicating the presence of a mechanism related to the regeneration of salivary gland tissue.
\end{abstract}

Key words: Salivary gland, Duct ligation, Atrophy, Terminal tubule cell, PSCA

\section{Introduction}

Salivary gland hypofunction results in decreased saliva secretion, thus reducing the mouth's physiological function and its defense against infection. This can bring about a marked deterioration in a patient's quality of life. Clinically, reduced saliva secretion can be caused by dysfunction as a result of radiation therapy for head and neck carcinoma ${ }^{1}$, autoimmune disorders such as Sjögren's syndrome ${ }^{2}$, chronic inflammatory lesions due to diabetes or salivary calculus ${ }^{3)}$, or degenerative changes due to age ${ }^{4}$. There are currently no therapeutic strategies for recovering gland tissue or diminished or lost salivary secretion function. Experiments in cell transplantation are currently underway with the aim of introducing clinical therapy for salivary gland regeneration ${ }^{5}$. It is essential to have a firm understanding of the self-renewal capability remaining in the salivary gland of the

Correspondence to: Dr. Keita Akadomari, Department of Oral and Maxillofacial Surgery, School of Life Dentistry at Niigata, The Nippon Dental University, 1-8 Hamaura-chou, Chuo-ku, Niigata city, Niigata, 951-8580 Japan; Phone: +81-25-267-1500; Fax: +81-25-267-1795; Email: red-k@ngt.ndu.ac.jp recipient, which will be the substrate onto which cells are transplanted; therefore, there is a pressing need to investigate the optimal conditions for transplantation and to establish a model of salivary gland atrophy.

Here we investigate the expression of various factors involved in the residual regenerative ability of atrophied salivary glands by ligating the main excretory ducts of the submandibular glands in mice for different lengths of time and comparing the results using histochemical staining with markers to detect acinar and stem cells. We used terminal deoxynucleotidyl transferase dUTP nick end labeling (TUNEL) staining to detect apoptosis and reverse transcription polymerase chain reaction (RT-PCR) to analyze gene expression.

\section{Materials and Methods}

\section{Experimental animals}

The experimental animals were 8-week-old female ICR mice (CLEA Japan, Tokyo, Japan). They were kept in a 12-h light and dark cycle with free access to pellets (MF, Oriental Yeast Co., 
J.Hard Tissue Biology Vol. 25(2):121 -130, 2016

Table 1 . The primary antibodies used for immunohistochemistry

\begin{tabular}{lll}
\hline Antibodies & Source (Catalog no.) & Dilution \\
Anti- $\alpha$-amylase antibody & Sigma-Aldrich (A8273) & $1: 100$ \\
Anti-AQP5 antibody & Abcam (ab104751) & $1: 1000$ \\
Anti-c-Kit antibody & Abcam (ab5506) & $1: 100$ \\
Anti-PSCA antibody & Abcam (ab56338) & $1: 100$ \\
\hline
\end{tabular}

AQP5: aquapolin 5; PSCA: prostate stem cell antigen

Table 2. The PCR primers

\begin{tabular}{lll}
\hline Target gene & Primer sequence $(52-32)$ & GenBank accession no. \\
\hline$\alpha$-amylase & F:GACGAACTGCTATTATCCACCTG & NM_007446 \\
& R:GTTGCACCTGTTCACCATGTC & \\
FQP5 & R:AGAAGGAGGTGTGTTCAGTTGC & NM_009701 \\
& F:GGACCAGCACAGTTGCTTTAC & \\
PSCA & R:GTAGTTCTCCGAGTCATCCTCA & NM_028216 \\
c-Kit & F: GCTGACTATCAGCTCGGCAA & \\
& R:GGCCTGGATTTGCTCTTTGT & NM_001122733.1 \\
GAPDH & R:TCATGACATCAAGAAGGTGGTGAAG & NM_008084 \\
& & \\
\hline
\end{tabular}

F: forward; R: reverse; AQP5: aquapolin 5; PSCA: prostate stem cell antigen; GAPDH: glyceraldehyde-3-phosphate dehydrogenase

Ltd., Tokyo, Japan) and tap water. The mice were used for experimentation at 10 weeks of age, after a 2 -week period of environmental adaptation.

This study was approved by the experimental animal ethics committee of the Nippon Dental University School of Life Dentistry at Niigata (approval no. 129).

\section{Submandibular gland duct ligation and removal}

General anesthesia was administered by the intraperitoneal injection of $1 \mathrm{ml} / \mathrm{kg}$ pentobarbital sodium $(50 \mathrm{mg} / \mathrm{ml} \mathrm{Nembutal}$; Dainippon Pharmaceutical Co., Ltd., Osaka, Japan). The back was supported, and a midline skin incision was made in the neck. Peripheral tissues, including nerves and blood vessels, were detached, taking care not to damage them, exposing the main excretory duct of the left submandibular gland. The duct was ligated approximately $2 \mathrm{~mm}$ above the salivary gland using a 4-0 silk suture, and the wound was closed. The opposite side was not ligated and was used as a control. The period of ligation was 7 days (7-day ligation group), 14 days (14-day ligation group), or 21 days (21-day ligation group), with 5 mice in each group. After the ligation period, the mice were sacrificed with pentobarbital sodium, and the submandibular were glands removed. At the time of removal, a sample was first removed for RT-PCR analysis, after which blood and fluids were cleared using phosphate-buffered saline (PBS) administered to the left ventricle, and perfusion fixation was conducted with $4 \%$ paraformaldehyde (PFA). The submandibular glands were then removed.

\section{Histological examination}

The extracted submandibular gland was immersion fixed in 4 $\%$ PFA for $48 \mathrm{~h}$ and was then embedded in paraffin in accordance with standard protocols. Sections $(5 \mu \mathrm{m})$ were prepared and stained with hematoxylin and eosin (HE) and periodic acid-Schiff (PAS) stains. Histological examination was performed under an optical microscope (Olympus BX51; Olympus, Tokyo, Japan).

\section{TUNEL staining}

TUNEL staining was performed using the In Situ Cell Death Detection Kit Fluorescein (Roche Diagnostics, Mannheim, Germany) to detect apoptosis. The paraffin was removed, and antigen retrieval was performed in accordance with standard protocols. The TUNEL reaction mixture $(50 \mu \mathrm{l} / \mathrm{slide})$ was then allowed to act on the sample for $60 \mathrm{~min}$ at $37^{\circ} \mathrm{C}$. Nuclear staining with 42 ,6-diamidino-2-phenylindole (DAPI; Vector Laboratories, Burlingame, CA) was performed, and the sections were embedded. They were examined using a fluorescence microscope (BZ-9000; Keyence, Osaka Japan).

\section{Immunohistochemical examination}

The paraffin was removed and antigen retrieval was performed in accordance with standard protocols. Non-specific reaction blocking was performed using $1 \%$ bovine serum albumin (BSA)/ 
Keita Akadomari et al.: PSCA Expression of Atrophic Submandibular Gland

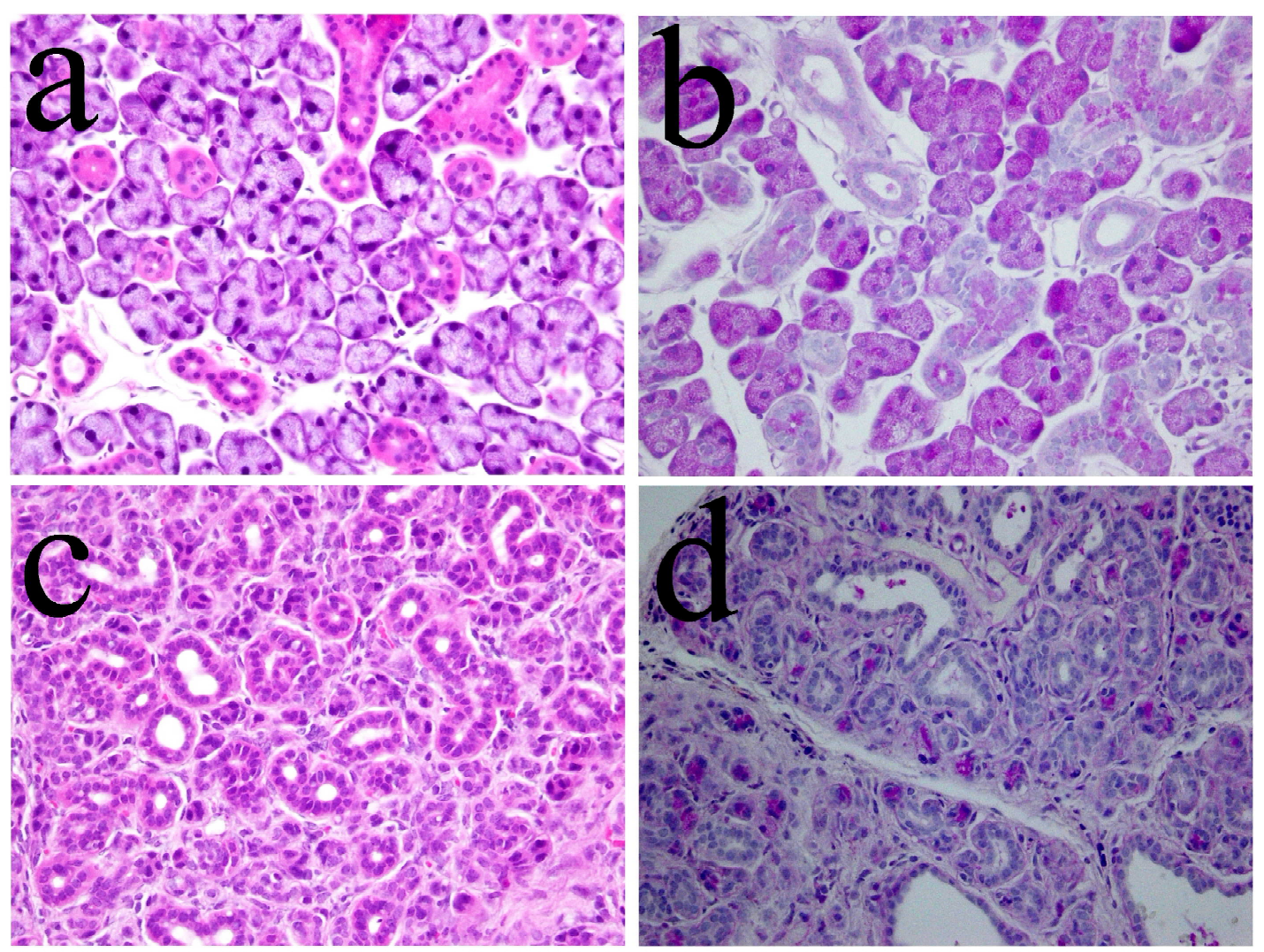

Figure 1. Histopathological changes in submandibular glands. a: Non-surgically treated gland (HE stain); b: Non-surgically treated gland (PAS stain); c: 21 days after duct ligation (HE stain); d: 21 days after duct ligation (PAS stain) (Bars $=100 \mu \mathrm{m})$.
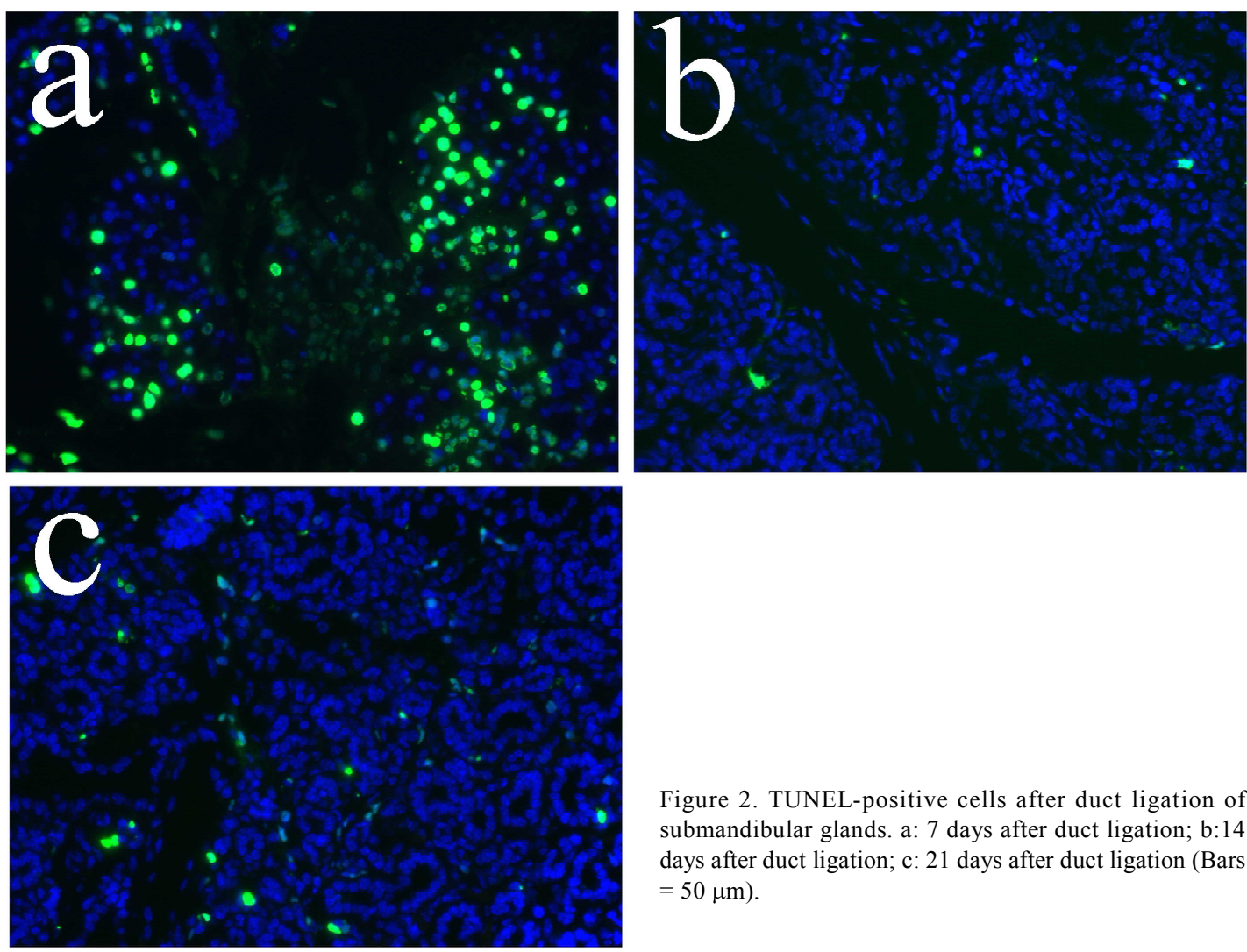

Figure 2. TUNEL-positive cells after duct ligation of submandibular glands. a: 7 days after duct ligation; b:14 days after duct ligation; $\mathrm{c}: 21$ days after duct ligation (Bars $=50 \mu \mathrm{m})$. 

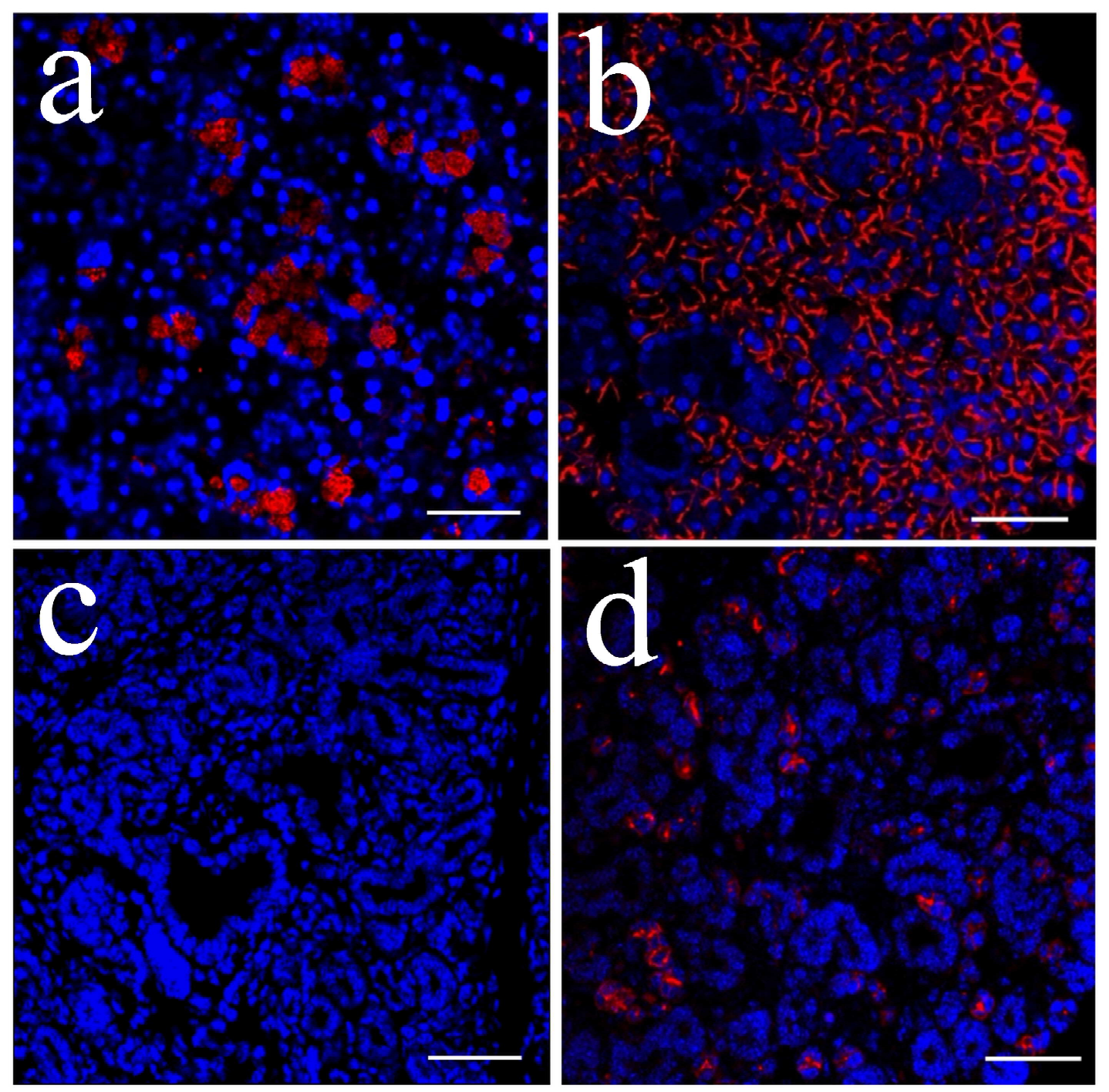

Figure 3. Immunohistochemistry for á-amylase and AQP5. a: Non-surgically treated gland (á-amylase); b: Non-surgically treated gland (AQP5); c: 21 days after duct ligation (á-amylase); d: 21 days after duct ligation (AQP5) (Bars = $50 \mu \mathrm{m}$ ).

PBS for $30 \mathrm{~min}$ at room temperature. Sections were reacted overnight with the primary antibody at $4{ }^{\circ} \mathrm{C}$ and then with the secondary antibody for $2 \mathrm{~h}$ at room temperature. Nuclear staining was performed, and the sections were embedded. These were examined using a confocal laser scanning microscope (LSM 710; Carl Zeiss, Germany). The antibodies used are shown in Table 1.

\section{Gene expression analysis}

Differences in protein expression between the groups were investigated using RT-PCR. Extracted tissues were immersed in RNA and then in RNA stabilization reagent for storage until use. Total RNA was extracted using RNeasy mini kit (QIAGEN, Hilden, Germany), and cDNA was synthesized using High Capacity cDNA Reverse Transcription Kit (ABI). Primers were for the same targets as the immunohistochemical staining, and the housekeeping gene glyceraldehyde-3-phosphate dehydrogenase (GAPDH) was used as a control. The primer sequences are shown in Table 2 .

\section{Results}

\section{Histological findings}

In the submandibular gland of the control group, acinar cells presented as a circular or oval external shape, and the nuclei were displaced toward the basal end of the cell. Identifiable duct tissue included the intercalated duct, granular convoluted tubule, and striated duct (Fig. 1a). In addition, PAS-positive secretory granules were observed in the cytoplasm (Fig. 1b). In the 7-day ligation group, the structure that was probably the acinus was almost completely lost, and the residual ducts were crowded together. There was a clear increase in interlobular connective tissue, and the lumen was enlarged. The 14- and 21-day ligation groups exhibited the same histology, but it became progressively more difficult to identify the intercalated duct, granular convoluted tubule, and striated duct, and numerous duct-like structures with diameters slightly smaller than acinar cells had appeared (Fig. 1c, d). 

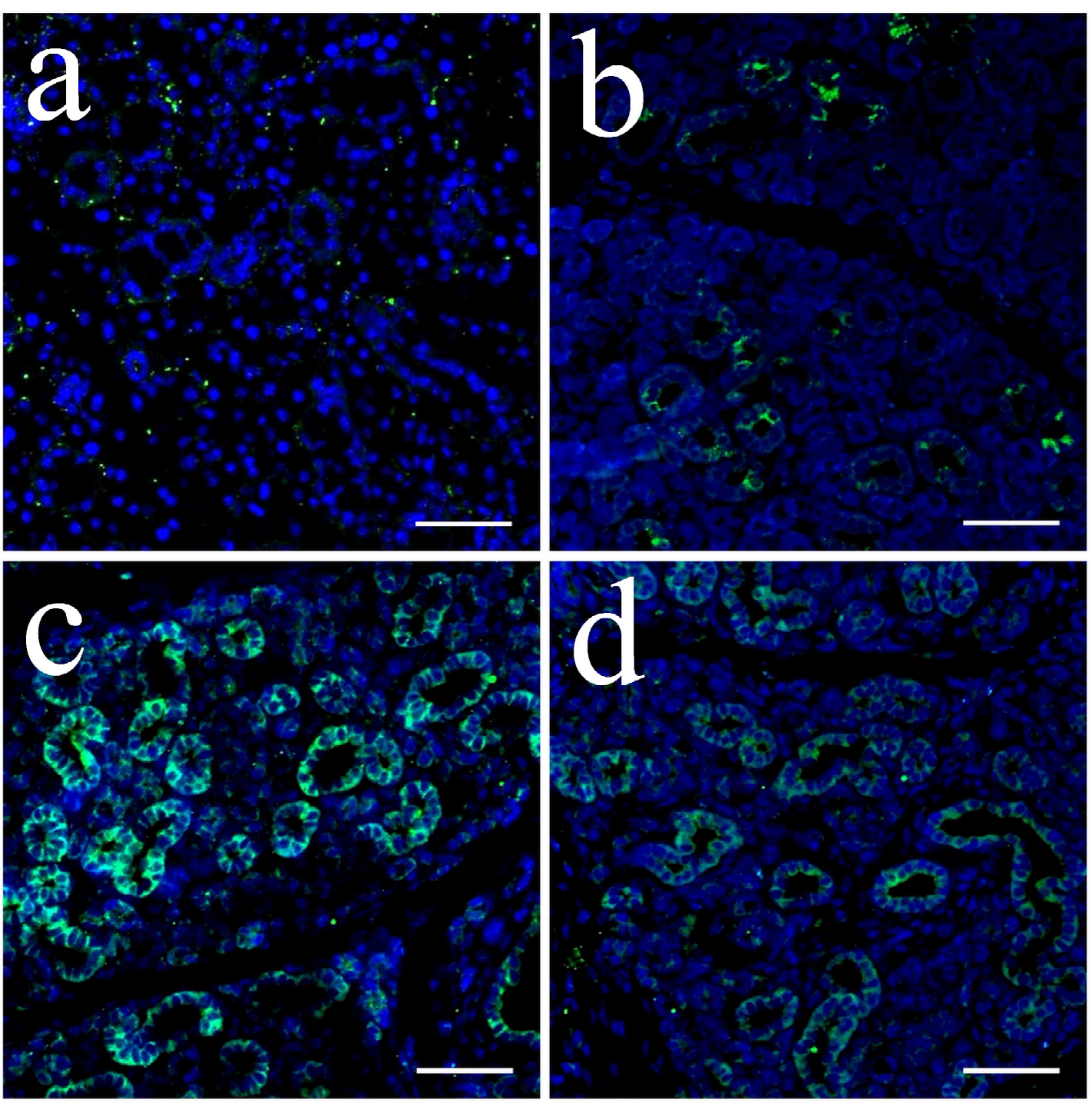

Figure 4. Immunohistochemistry for PSCA. a: Non-surgically treated gland; b: 7 days after duct ligation; c: 14 days after duct ligation; $\mathrm{d}: 21$ days after duct ligation $(\operatorname{Bars}=50 \mu \mathrm{m})$.

\section{TUNEL staining}

Prior to ligation, there were very few TUNEL-positive cells, but numerous TUNEL-positive cells, mainly atrophied acinar cells, were observed in the 7-day ligation group. Their number slightly decreased in the 14-day ligation group and increased again in the 21-day ligation group (Fig. 2a, b, c).

\section{Immunohistochemical findings}

In the normal (non-ligated) submandibular gland, a strong positive á-amylase reaction was observed in the cytoplasm of acinar cells, and a strong positive aquapolin 5 (AQP5) reaction was seen in the cellular membrane of acinar cells (Fig. 3a, b). Positive reactions for á-amylase and AQP5 decreased over time after ligation with the loss of acinar cells. In the 21-day ligation group, there was almost no reaction for á-amylase (Fig. 3c), whereas a positive reaction for AQP5 was observed in some of the duct-like structures (Fig. 3d). Prostate stem cell antigen (PSCA) and c-Kit both showed a faint positive reaction in localized areas of the duct epithelium of the normal submandibular gland (Figs. $4 a, 5 a)$. In the 7-day ligation group, there was a greater positive reaction than in the normal gland (Figs. $4 b, 5 b$ ), and the positive reaction was the greatest in the 14-day ligation group (Figs. 4c, $5 \mathrm{c})$. In the 21-day ligation group, the positive reaction had slightly decreased (Figs. 4d, 5d). Furthermore, on PSCA and c-Kit double staining of the ligated submandibular gland, both had accumulated in the duct-like structures, and their distribution coincided (Fig. 6a-d).

\section{Gene analysis}

From 7 days onward after ligation, á-amylase had completely disappeared. AQP5 showed a reduction in expression over time in comparison to that in the normal submandibular gland, but 

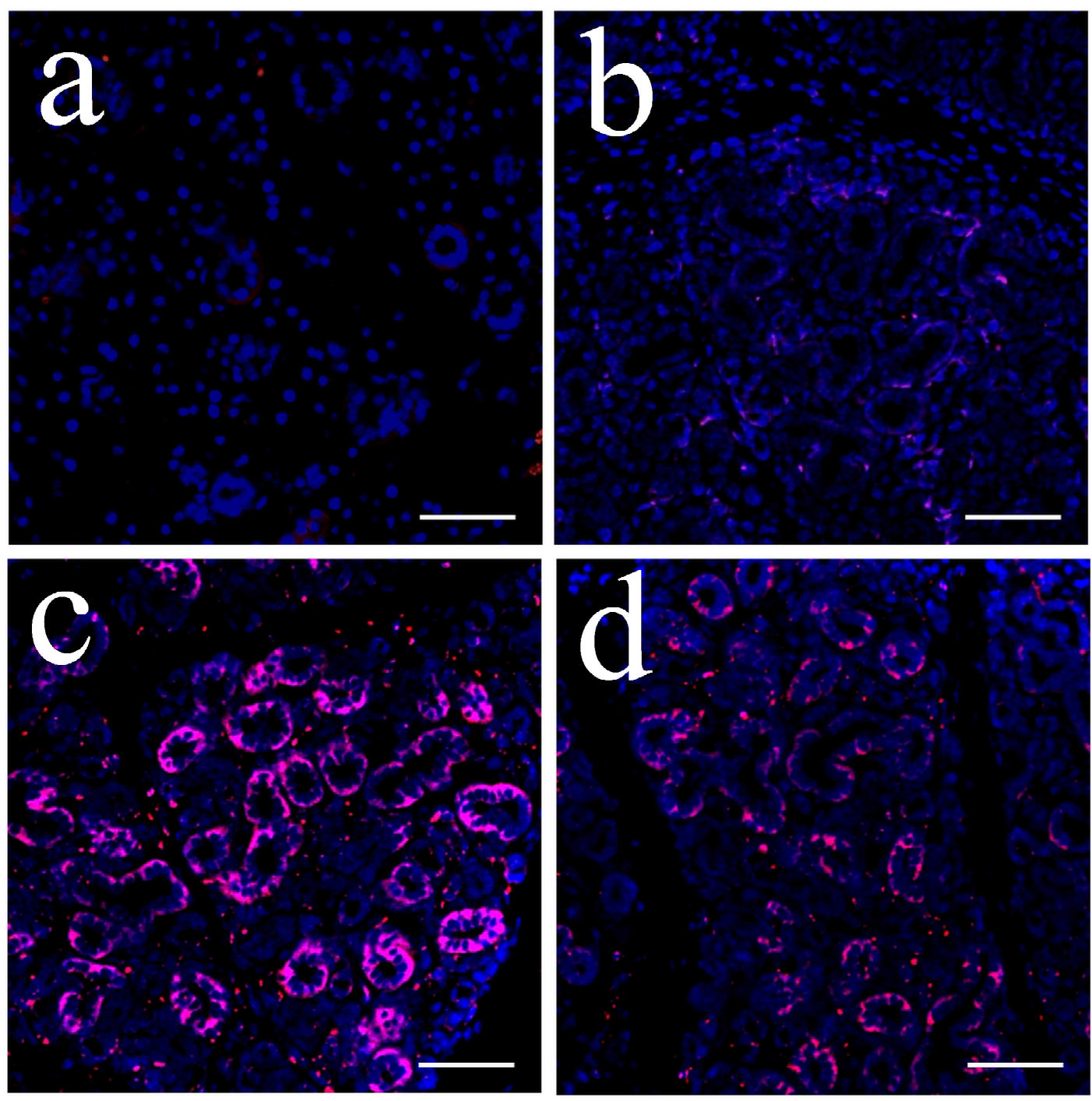

Figure 5. Immunohistochemistry for c-Kit. a: Non-surgically treated gland; b: 7 days after duct ligation; c: 14 days after duct ligation; $\mathrm{d}: 21$ days after duct ligation $($ Bars $=50 \mu \mathrm{m})$.

of blastema needed for regeneration is under the control of the cells in apoptosis ${ }^{40)}$. Thus, cells in apoptosis are the trigger for tissue regeneration. Tissue regenerative ability varies according to the organ and developmental stage, but it appears that if a tissue is damaged, there is rapid growth and differentiation of stem cells, allowing the tissue to regenerate ${ }^{40-42)}$. In addition, stem cells in living organism are usually in a resting state or are slowly undergoing the cell cycle. If cells die or are damaged, the stem cells react by becoming activated ${ }^{43)}$. The proliferation of intercalated duct cells and myoepithelial cells is observed in sialadenitis, and the process of tissue repair by inflammation is conjectured to be the same as the process of new cell birth in healthy tissue ${ }^{44)}$. In the present study, undifferentiated markers were strongly expressed in duct-like structures during the period when apoptosis in the acinar cells was weakening. This is a finding of enormous interest because it suggests the possibility that a mechanism with similar timing to the period of tissue morphogenesis during the embryonic stage is expressed in the atrophied salivary gland. In addition, a submandibular gland that has atrophied as a result of ligation shows an increase in stem cell markers in comparison to a normal submandibular gland. From this, it appears that the apoptosis caused by ligation activates the regenerative ability, leading to an increase in stem cells. These findings suggest that apoptosis in acinar cells induced by ligation is involved in the multifaceted control of the phenomenon of gland tissue regeneration and that stem cells are strongly linked to apoptosis.

Here using a model of submandibular gland atrophy resulting from duct ligation, we identified in the 14- and 21-day ligation groups the possibility that acinar cells in duct-like structures expressed as a result of atrophy possess the potential for differentiation. Consequently, if the present model of atrophy is 

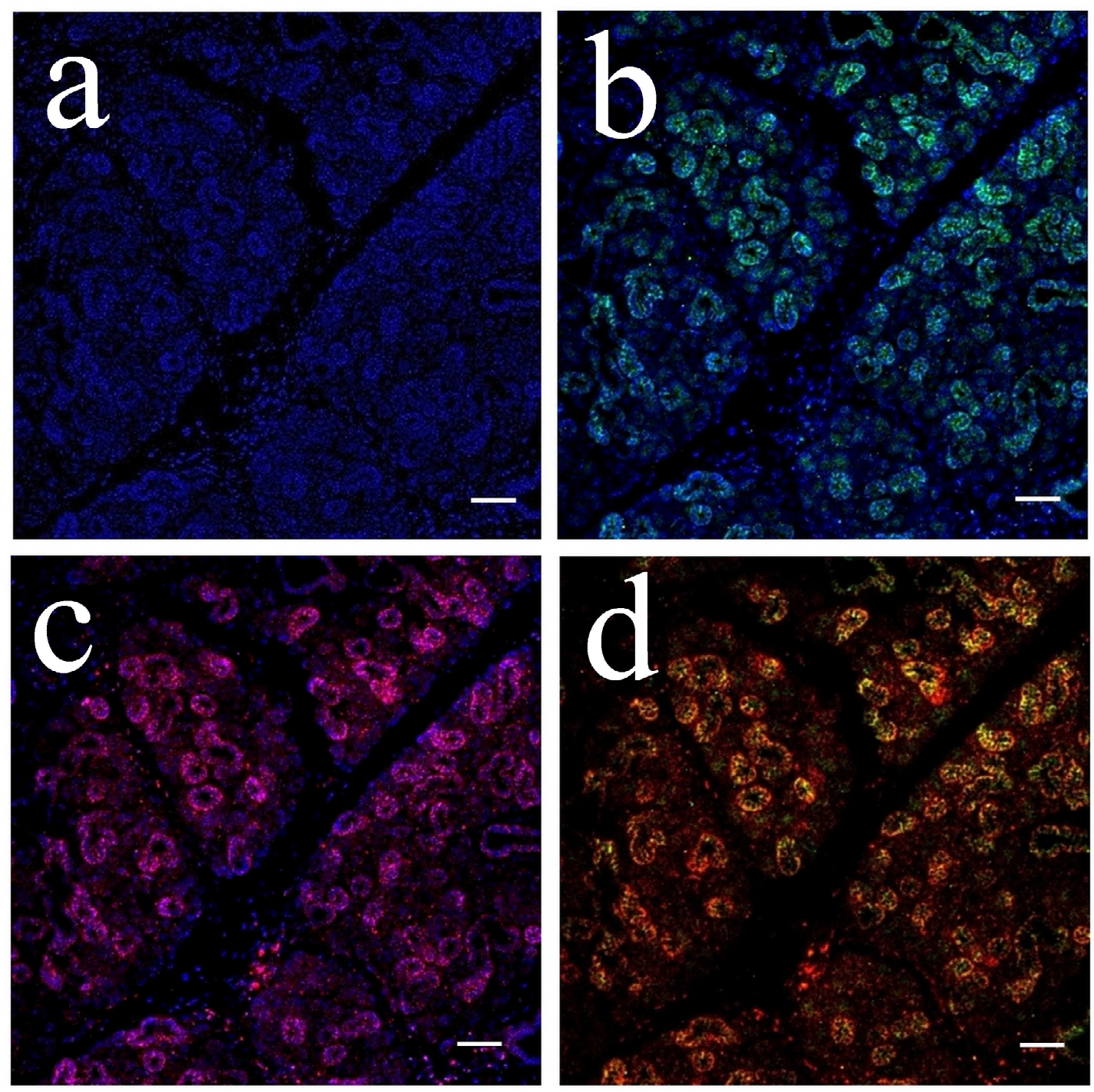

Figure 6. Immunohistochemistry for PSCA and c-Kit. a: Nuclei alone (DAPI); b: PSCA at 14 days after duct ligation; c: c-Kit at 14 days after duct ligation; d: PSCA and c-Kit double staining at 14 days after duct ligation $($ Bars $=50 \mu \mathrm{m})$.

expression was still found in the 21-day ligation group. The expression of both PSCA and c-Kit increased after ligation in comparison to that of the normal submandibular gland, with the greatest expression found in the 14-day ligation group (Fig. 7).

\section{Discussion}

Several studies have investigated tissue changes in the glandular parenchyma as a result of ligation of the main excretory duct of the submandibular gland; all have reported acinar cell atrophy, increase in interlobular connective tissue, and enlargement of the lumina as histological changes ${ }^{6-13}$. Here we investigated the expression of the water channel protein AQP5, a marker for acinar cells ${ }^{14-16)}$, in mice and of the secretase $\alpha$-amylase ${ }^{17,18)}$ after different periods of ligation to evaluate the function of residual acinar cells. A decrease in expression over time was found in both
AQP5 and $\alpha$-amylase following ligation, but AQP5 expression was still found in the vicinity of the duct-like structures, even after 21 days of ligation. This suggests that there was residual acinar cell function. The results of immunostaining and RT-PCR both showed the same differences between AQP5 and $\alpha$-amylase, and $\alpha$-amylase had practically disappeared in the 7-day ligation group. However, as AQP5 is expressed ahead of $\alpha$-amylase in the process of acinus morphogenesis during the embryonic stage, it is likely that AQP5 and $\alpha$-amylase have different expression periods ${ }^{16-18)}$. The results also suggest that the duct-like structures have the potential to differentiate into acinar cells, even in the 21day ligation group, and AQP5 appears to have served as a marker for this. Ligation of the main excretory duct of the submandibular gland is believed to result in atrophy of acinar cells because dysfunction in salivary excretion causes degenerative changes in 


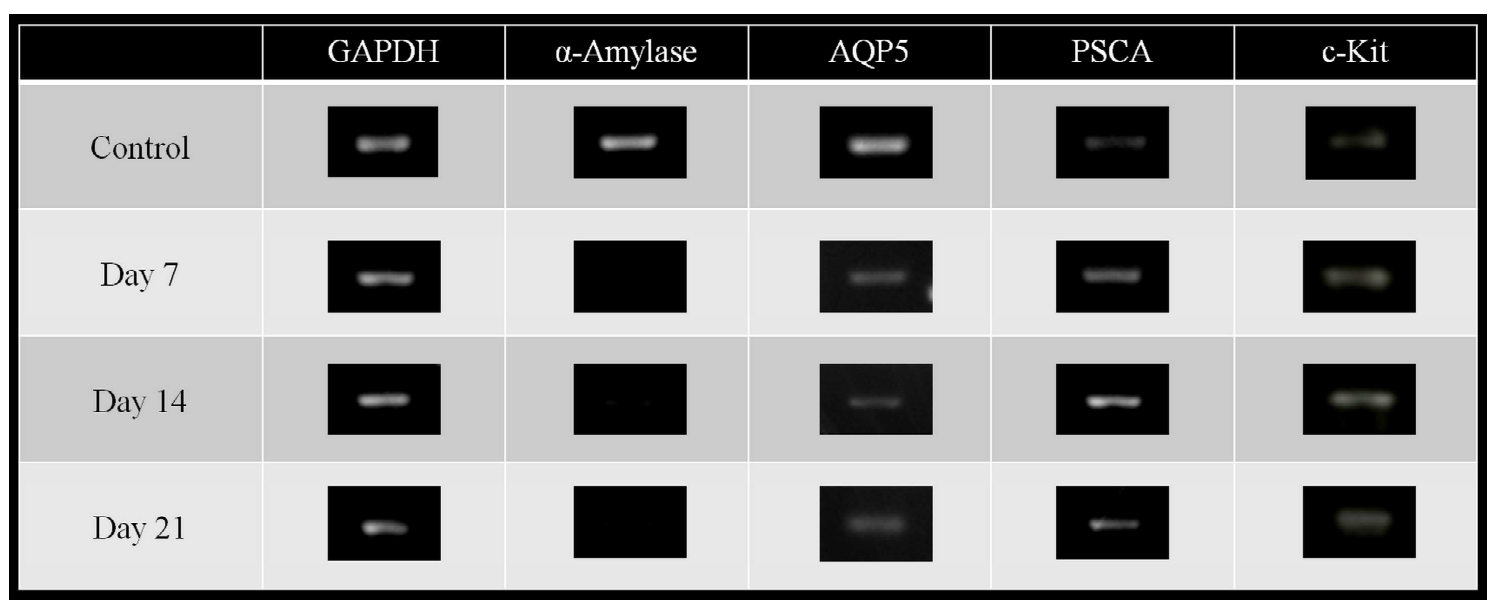

Figure 7. RT-PCR of GAPDH, $\alpha$-amylase, AQP5, PSCA, and c-Kit at 7, 14, and 21 days after duct ligation.

glandular tissue, resulting in atrophy of the glandular parenchyma. In addition, duct-like structures with the potential to differentiate into acinar cells start to appear during the acinar cell regeneration period in atrophied salivary glands ${ }^{7,19}$. These tubular duct-like structures are not found in mature salivary glands but only in atrophied salivary glands. They are composed of cells with the same characteristics as terminal tubule cells, which appear during salivary gland development; therefore, it is thought that acinar cells differentiate from these terminal tubule cells ${ }^{20,21}$. It has been reported that a major portion of the submandibular gland during postnatal growth is made up of connective tissue and that there are no mature acinar cells in the acini. The terminal tubule cells vigorously proliferate and account for majority of cells in the $\operatorname{acini}^{20,22)}$. The proportion of terminal tubule cells subsequently begins to decrease as the number of mature-form acinar cells increases. As this occurs, apoptosis accompanying the fragmentation of nuclei may be observed under an electron microscope in some terminal tubule cells. Terminal tubule cells are believed to subsequently transform into intercalated duct cells $^{23)}$

Development of the salivary gland begins with the thickening of the oral epithelium, which invaginates to form a cord into the mesenchymal tissue directly below. Formation of the ducts progresses as the epithelial mass, which stretches into a cord, undergoes branching morphogenesis, repeatedly bifurcating and growing ${ }^{24,25)}$. This pattern of development is also seen in the prostate gland ${ }^{25)}$. The prostate gland is reported to have a ductal epithelial tissue regenerative ability, even though vigorous cell proliferation is not observed ${ }^{26)}$, and PSCA is believed to be expressed in the progenitor cell group in the differentiation process of regeneration ${ }^{27,28)}$. In experiments to identify undifferentiated cells in the prostate gland, PSCA expression has been reported in undifferentiated cells with cell proliferation activity and is considered to be a marker for prostate gland stem cell ${ }^{28,29)}$. Similar expression is, therefore, likely to be found in progenitor groups in the salivary gland cells that undergo differentiation, proliferation, and morphogenesis in the same way. The multilineage potential of salivary glands during the regeneration process has attracted attention for some time, and epithelial cells obtained from salivary glands that atrophied following ligation have been reported to differentiate into hepatic and pancreatic cells ${ }^{30)}$. This indicates the presence of somatic stem cells that are capable of differentiation into both acinar cells and more widely, into endodermal gland cells. The salivary gland may, therefore, effectively provide stem cells for other endodermal gland tissues. Studies of salivary gland stem cells have reported c-Kit, Sca-1, and Musashi-1 as stem cell markers ${ }^{17,31-35)}$. There are also a number of reports mentioning that epithelial stem cells of the salivary gland duct are present in intercalated ducts ${ }^{36,37)}$ and that they are present in the duct-like structures of atrophied salivary glands ${ }^{7,38)}$. In addition, differentiated cells are reported to participate in regeneration $^{38,39)}$. In the present study, we found PSCA in the intercalated ducts of normal submandibular glands and c-Kit in the duct-like structures of atrophied salivary glands. On double staining for PSCA and c-Kit, positive reactions for both were observed in the same areas. This indicates that, as for the prostate gland, PSCA is a useful marker for undifferentiated stem cells in the salivary gland.

Apoptosis in tissue that had atrophied as a result of ligation was evaluated by TUNEL staining. The greatest proportion of the total number of cells that showed a positive reaction for apoptosis was in the 7-day ligation group, with a reduction in the number of apoptosis-positive cells observed in the 14-day ligation group. However, the 14-day ligation group also showed the greatest number of positive reactions for c-Kit, considered to be a marker for salivary gland stem cells, and for PSCA, considered to be a marker for prostate stem cells. Thus, the results for the period of PSCA and c-Kit expression are contrary to the TUNEL staining results. Apoptosis is believed to be the beginning of cell proliferation in the tissue regeneration process, and the formation 
Keita Akadomari et al.: PSCA Expression of Atrophic Submandibular Gland

used for salivary gland regeneration experiments that involve transplantation, it would be extremely difficult to rigorously evaluate the tissue regeneration resulting from the transplant because of the undeniable possibility that the remaining tissue in the atrophy model has the potential for regeneration. A detailed investigation is needed of the stem cell markers and other factors involved in the process of acinar cell regeneration, through experiments, in which ligation is removed. PSCA and AQP5 are likely to be useful markers in this respect. There also appears to be a need to investigate the changes in submandibular gland tissue in a model of atrophy with ligation of more than 21 days.

\section{Conflict of Interest}

The authors have declared that no COI exists.

\section{References}

1. Kahn ST and Johnstone PA. Management of xerostomia related to radiotherapy for head and neck cancer. Oncology 19: 1827-1832, 2005

2. Fox R. Sjogren's syndrome. Lancet 366: 321-31, 2005

3. Roescher N, Lodde BM, Vosters JL, Tak PP, Catalan MA, Illei GG and Chiorini JA. Temporal changes in salivary glands of non-obese diabetic mice as a model for Sjögren's syndrome. Oral Dis 18: 96-106, 2012

4. Desoutter A, Soudain-Pineau M, Munsch F, Mauprivez C, Dufour T and Coeuriot JL. Xerostomia and medication: a cross-sectional study in long-term geriatric wards. J Nutr Health Aging 16: 575-579, 2012

5. Kawakami M, Ishikawa H, Tachibana T, Tanaka A and Mataga I. Functional transplantation of salivary gland cells differentiated from mouse early ES cells in vitro. Human Cell 26: 80-90, 2013

6. Bhaskar SN, Lilly GE and Bhussry B. Regeneration of the salivary glands in the rabbit. J Dent Res 45: 37-41, 1966

7. Tamarin A. Submaxillary gland recovery from obstruction. I. Overall changes and electron microscopic alterations of granular duct cells. J Ultrastruct Res 34: 276-287, 1971

8. Tamarin A. Submaxillary gland recovery from obstruction. II. Electron microscopic alterations of acinar cells. J Ultrastruct Res 34: 288-302, 1971

9. Zaia AA, Della Coletta R, Almeida OP and Line SR. Expression of collagen and elastic fibers in duct-ligated submandibular glands of mice. Eur J Oral Sci 104: 627629, 1996

10. Burgess K, Dardick I, Cummins MM and Burford-Mason AP, Basset R and Brown DH. Myoepithelial cells actively proliferate during atrophy of rat parotid gland. Oral Surg Oral Med Oral Pathol Oral Radiol Endod 82: 674-680, 1986

11. Scott J. Quantitative age changes in the histological structure of human submandibular salivary glands. Arch Oral Biol

$$
\text { 22: 221-227, } 1977
$$

12. Takahashi S, Yoshimura Y, Yamamoto T and Wakita M. Cellular expression of Bcl-2 and Bax in atrophic submandibular glands of rats. Int J Exp Pathol 89: 303-308, 2008

13. Shiratsuchi H, Shimizu O, Saito T, Mashimo $\mathrm{T}$ and Yonehara Y. Immunohistological study of small Rho GTPases and bcatenin during regeneration of the rat submandibular gland. J Mol Histol 43: 751-759, 2012

14. Cotroneo E, Proctor GB, Paterson KL and Carpenter GH. Early markers of regeneration following ductal ligation in rat submandibular gland. Cell Tissue Res 332: 227-235, 2008

15. Cotroneo E, Proctor GB and Carpenter GH. Regeneration of acinar cells following ligation of rat submandibular gland retraces the embryonic-perinatal pathway of cytodifferentiation. Differentiation 79: 120-130, 2010

16. Larsen HS, Aure MH, Peters SB, Larsen M, Messelt EB and Galtung HK. Localization of AQP5 during development of the mouse submandibular salivary gland. J Mol Histol 42: $71-81,2011$

17. Maria OM, Maria AM, Cai1 Y and Tran SD. Cell surface markers CD44 and CD166 localized specific populations of salivary acinar cells. Oral Dis 18: 162-168, 2012

18. Minematsu Y. The production and localization of alphaamylase during the embryonic development of mouse submandibular gland. J Hiroshima Univ Dent Soc 20: 243255, 1988

19. Minabe_M. Regeneration of the rat submandibular glands after duct ligation. Kanagawa Shigaku 24: 484-500, 1989

20. Jacoby F and Leeson CR. The postnatal development of the rat submaxillary gland. J Anat 93: 201-216, 1959

21. Hanks CT and Chaudhry AP. Regeneration of rat submandibular gland following partial extirpation. A light and electron microscopic study. Am J Anat 130: 195-208, 1971

22. Alvares EP and Sesso A. Cell proliferation, differentiation and transformation in the rat submandibular gland during early postnatal growth. A quantitative and morphological study. Arch Histol Jpn 38: 177-208, 1975

23. Hayashi H. Morphological changes of the intercalated duct cells associated with the postnatal development of the mouse submandibular gland. Kanagawa Shigaku 21:332-349, 1986

24. Tucker AS. Salivary gland development. Semin Cell Dev Biol 18: 237-244, 2007

25. Gresik_EW, Koyama N, Hayashi T and Kashimata M. Branching morphogenesis in the fetal mouse submandibular gland is codependent on growth factors and extracellular matrix. J Med Invest 56: 228-233, 2009

26. English HF, Kyprianou N and Isaacs JT. Relationship between DNA fragmentation and apoptosis in the 
J.Hard Tissue Biology Vol. 25(2):121 -130, 2016

programmed cell death in the rat prostate following castration. Prostate 15: 233-250, 1989

27. Tran CP, Lin C, Yamashiro J and Reiter RE. Prostate stem cell antigen is a marker of late intermediate prostate epithelial cells. Mol Cancer Res 1: 113-121, 2002

28. Watabe T, Lin M, Ide H, Donjacour AA, Cunha GR, Witte $\mathrm{ON}$ and Reiter RE. Growth, regeneration, and tumorigenesis of the prostate activates the PSCA promoter. Proc Natl Acad Sci U S A 99: 401-406, 2002

29. Reiter RE, Gu Z, Watabe T, Thomas G, Szigeti K, Davis E, Wahl M, Nisitani S, Yamashiro J, Le Beau MM, Loda M and Witte ON. Prostate stem cell antigen: a cell surface marker overexpressed in prostate cancer. Proc Natl Acad Sci U S A 95: 1735-1740, 1998

30. Okumura K, Nakamura K, Hisatomi Y, Nagano K, Tanaka Y, Terada K, Sugiyama T, Umeyama K, Matsumoto K, Yamamoto $\mathrm{T}$ and Endo F. Salivary gland progenitor cells induced by duct ligation differentiate into hepatic and pancreatic lineages. Hepatology 38: 104-113, 2003

31. Hisatomi Y, Okumura K, Nakamura K, Matsumoto S, Satoh A, Nagano K, Yamamoto T and Endo F. Flow cytometric isolation of endodermal progenitors from mouse salivary gland differentiate into hepatic and pancreatic lineages. Hepatology 39: 667-675, 2004

32. Lombaert IMA, Brunsting JF, Wierenga PK, Faber H, Stockman MA, Kok T, Visser WH, Kampinga HH, Haan GD and Coppes RP. Rescue of salivary gland function after stem cell transplantation in irradiated glands. PLoS ONE 3: e2063, 2008

33. Feng J, Zwaag MVD, Stokman MA, Os RV and Coppes RP. Isolation and characterization of human salivary gland cells for stem cell transplantation to reduce radiationinduced hyposalivation. Radiother Oncol 92: 466-471, 2009

34. Nanduri LSY, Maimets M, Pringle SA, Zwaag MVD, Os RPV and Coppes RP. Regeneration of irradiated salivary glands with stem cell marker expressing cells. Radiother Oncol 99: 367-372, 2011

35. Purwanti N, Tsuji D, Azlina A, Karabasil MR, Javkhlan P, Hasegawa T, Yao C, Akamatsu T, Itoh K and Hosoi K. Induction of Sca-1 in the duct cells of the mouse submandibular gland by obstruction of the main excretory duct. J Oral Pathol Med 40: 651-658, 2011

36. Burgess KL and Dardick I. Cell population changes during atrophy and regeneration of rat parotid gland. Oral Surg Oral Med Oral Pathol Oral Radiol Endod 85: 699-706, 1998

37. Man YG, Ball WD, Marchetti L and Hand AR. Contributions of intercalated duct cells to the normal parenchyma of submandibular glands of adult rats. Anat Rec 263: 202-214, 2001

38. Takahashi S, Schoch E and Walker NI. Origin of acinar cell regeneration after atrophy of the rat parotid induced by duct obstruction. Int J Exp Pathol 79: 293-301, 1998

39. Ihrler S, Zietz C, Sendelhofert A, Lang S and Blasenbreu VS. A morphogenetic concept of salivary duct regeneration and metaplasia. Virchows Arch 440: 519-526, 2002

40. Fan Y and Bergmann A. Apoptosis-induced compensatory proliferation. The Cell is dead. Long live the Cell! Trends Cell Biol 18: 467-473, 2008

41. Poulsom R, Alison MR, Forbes SJ and Wright NA. Adult stem cell plasticity. J Pathol 197: 441-456, 2002

42. Presnell SC, Petersen B and Heidaran M. Stem cells in adult tissues. Semin Cell Dev Biol 13: 369-376, 2002

43. Bergmann A and Steller H. Apoptosis, stem cells, and tissue regeneration. Sci Signal 3: re8, 2010

44. Stephan I, Sabine BV, Andrea S, Matthias R, John D, Harrison and Udo L. Regeneration in chronic sialadenitis: an analysis of proliferation and apoptosis based on double immunohistochemical labeling. Virchows Arch 444: 356361,2004 